\title{
A CASE OF TROPICAL EOSINOPHILIA AND ACUTE NEPHRITIS
}

\author{
BY \\ J. D. PICKUP and IAN D. RILEY \\ From the Department of Paediatrics and Child Health, University of Leeds
}

(Received for Publication August 21, 1950)

Renal lesions have not been described in any of the cases of tropical eosinophilia so far reported.

This paper describes an attack of acute nephritis during the course of tropical eosinophilia.

\section{Case Report}

J.H. was a girl of 6 years who was admitted to St. James's Hospital, Leeds, on January 11, 1947, because of swelling of the face and albuminuria.

The child was well until January 6, 1947, when she developed a cough. Five days later her face and legs became swollen.

She had had measles and mumps in infancy, but no other illnesses. Two years previously she had come to Britain from India where she was born. She had suffered from 'wheezing' attacks for two years.

There was no history of worm infestation or any tropical infection.

The father was British and had been killed in action, and the stepfather was also British. The mother said that she and all her forebears were British. She was healthy, but had an illness diagnosed as 'chyluria' in July, 1947, which, it was assumed, was due to filariasis, although the parasite was never isolated.
On admission it was seen that the oedema had subsided, but there was a trace of albumin and scanty red cells in the urine. The child was discharged after 10 days in hospital, but five weeks later developed a painful cough and fever and was readmitted on March 26.

There was a large quantity of albumin in the urine at this time, and a few red cells on microscopical examination. Scattered râles were present in the chest. She was again discharged on May 30, but three days later developed generalized oedema and albuminuria accompanied by mild bronchitis, and was readmitted on June 4 . Widespread rhonchi and râles were present in the chest. A blood count showed marked eosinophilia. A radiograph of the chest revealed scattered mottling described by the radiologist as ' coarsening of the lung mesh.'

The urine gradually returned to normal, but otherwise the child's condition remained virtually unchanged with a constant eosinophilia (see Table 1) until July 29 , when 0.1 g. of N.A.B. was given followed by six injections of $0.1 \mathrm{~g}$. at weekly intervals. From this time there was a steady improvement in the clinical condition. The eosinophilia had disappeared by August 28. The blood sedimentation rate (Westergren) fell from $58 \mathrm{~mm}$. on May 28 to $1 \mathrm{~mm}$. on July 30 .

Re-examination two years later, on June 9, 1949,

TABLE 1

Differential Count

\begin{tabular}{|c|c|c|c|c|c|c|c|}
\hline Date & $\begin{array}{l}\text { Total White } \\
\text { Blood Cell } \\
\text { Count (per } \\
\text { c.mm.) }\end{array}$ & $\begin{array}{c}\text { Neutrophils } \\
(\%)\end{array}$ & $\begin{array}{c}\text { Eosinophils } \\
(\%)\end{array}$ & $\begin{array}{c}\text { Lymphocytes } \\
(\%)\end{array}$ & $\begin{array}{c}\text { Large } \\
\text { Monocytes } \\
(\%)\end{array}$ & $\begin{array}{c}\text { Smear } \\
\text { Cells } \\
(\%)\end{array}$ & $\begin{array}{c}\text { Basophils } \\
(\%)\end{array}$ \\
\hline 18.6.47 & & $\begin{array}{c}13 \cdot 5 \\
(27.400)\end{array}$ & $\begin{array}{c}50 \cdot 0 \\
(10.50)\end{array}$ & $\underset{(5887)}{29 \cdot 0}$ & $\begin{array}{c}1 \cdot 5 \\
(305)\end{array}$ & $5 \cdot 0$ & $\begin{array}{r}1.0 \\
(203)\end{array}$ \\
\hline $\begin{array}{r}2.7 .47 \\
24.7 .47\end{array}$ & $\begin{array}{l}22,400 \\
23,400\end{array}$ & $\begin{array}{l}19 \cdot 5 \\
31 \cdot 0\end{array}$ & $\begin{array}{l}39 \cdot 5 \\
41 \cdot 0\end{array}$ & $\begin{array}{l}36 \cdot 5 \\
26 \cdot 0\end{array}$ & $\begin{array}{r}1 \cdot 5 \\
2 \cdot 0\end{array}$ & & $3 \cdot 0$ \\
\hline 29.7.47 & \multicolumn{2}{|c|}{ N.A.B. treatment started } & & & & & \\
\hline $\begin{array}{r}4.8 .47 \\
15.8 .47 \\
23.8 .47 \\
29.8 .47 \\
5.9 .47 \\
9.6 .49\end{array}$ & $\begin{array}{r}16,700 \\
14,700 \\
13,400 \\
14,000 \\
9,000 \\
9,600 \\
6,500\end{array}$ & $\begin{array}{l}33 \cdot 0 \\
31 \cdot 0 \\
49 \cdot 0 \\
55 \cdot 0 \\
50 \cdot 0 \\
35 \cdot 0 \\
48 \cdot 0\end{array}$ & $\begin{array}{r}40 \cdot 0 \\
30 \cdot 0 \\
23 \cdot 0 \\
15 \cdot 0 \\
6 \cdot 0 \\
3 \cdot 0 \\
5 \cdot 0\end{array}$ & $\begin{array}{l}24 \cdot 0 \\
38 \cdot 0 \\
22 \cdot 0 \\
27 \cdot 0 \\
40 \cdot 0 \\
52 \cdot 0 \\
44 \cdot 0\end{array}$ & $\begin{array}{l}2 \cdot 0 \\
4 \cdot 0 \\
2 \cdot 0 \\
3 \cdot 0 \\
7 \cdot 0 \\
3 \cdot 0\end{array}$ & & $\begin{array}{l}1 \cdot 0 \\
1.0 \\
2 \cdot 0 \\
1 \cdot 0 \\
1 \cdot 0 \\
3 \cdot 0\end{array}$ \\
\hline
\end{tabular}

Dosage of N.A.B. was six injections each of $0 \cdot 1 \mathrm{~g}$. 
revealed no evidence of disease clinically or radiologically and the blood picture was normal.

Investigations. The following results were obtained during the periods in hospital.

The blood count is set out in Table 1 .

Blood pressure on June 16, 1947, was 110/70.

Sputum was examined on July 3, 4, 7, and 24, 1947, when no tubercle bacilli, mites, or eosinophils were present.

The Wassermann reaction was negative on July 11, 1947.

Stools were examined on June 19 and 28 and no parasites or ova were found.

The tuberculin reaction on May 6, 1947 (1/1,000 O.T.) was negative.

Urine analysis on several occasions gave the following results.

\begin{tabular}{|c|c|c|c|}
\hline Date & Albumin & Casts & R.B.C. \\
\hline $\begin{array}{l}18.6 .47 \\
\text { 23.7.47 }\end{array}$ & $\stackrel{+}{+}$ & Hyaline & Occasional \\
\hline $\begin{array}{r}10.9 .47 \\
9.6 .49\end{array}$ & 二 & 二 & 二 \\
\hline
\end{tabular}

B.S.R. (Westergren) readings were

28.5.47. $58 \mathrm{~mm}$. in 1 hour. $100 \mathrm{~mm}$. in 2 hours

23.7.47. $46 \mathrm{~mm}$. in 1 hour. $80 \mathrm{~mm}$. in 2 hours

30.7.47. $1 \mathrm{~mm}$. in 1 hour. $3 \mathrm{~mm}$. in 2 hours

A radiograph on June 19, 1947, showed an appearance of the lung fields indicating vascular engorgement, the features of which are enlargement of the root vessels with symmetrical coarsening of the lung mesh. Later radiographs (September 4) showed 'considerable reduction in pulmonary hyperaemia, now only increased in posterior and midbasic vessels,' and on September 24, ' marked improvement, increased vascularity of the lung mesh persists '; finally, on June 10, 1949, it was reported that 'the heart and lungs are now normal.'

A biopsy report on a gland from the left axilla and a portion of muscle from the left deltoid (Professor C. J. Polson, then pathologist at St. James's Hospital) stated:

\begin{abstract}
'Some of the vessels in the small lymph gland submitted contain a distinct excess of eosinophil polymorphs and here and there through the gland itself there are a number of eosinophils, and there is some histiocytic reaction. There is no evidence that this is Hodgkin's disease. The appearances are compatible with a parasitic infestation in the neighbourhood. Neither the lymph gland nor the small portion of striped muscle which accompanies it show evidence which would permit a diagnosis of periarteritis nodosa. It would appear that there is a distinct excess of eosinophils in the circulating blood.'
\end{abstract}

\section{Discussion}

Eosinophil counts of the height described are seldom seen apart from the condition known as tropical eosinophilia.
Frimodt-Möller and Barton (1940), and Weingarten (1943) independently described a condition seen in India resembling pulmonary tuberculosis in its insidious febrile onset, $x$-ray appearances, and wasting progress. Asthma was frequently present, very high eosinophilia was the rule, and, as Weingarten showed, arsenic was a specific cure. The x-ray appearances resembled those of miliary tuberculosis, a diffuse mottling of all parts of the lung being present.

There are numerous case reports in the literature, chiefly from India, but also from Africa and Australia. Those from Britain were all of persons recently returned from the tropics (Apley and Grant, 1944, 1945; Lal, 1945; Treu, 1943, 1944; Irwin, 1946; Stephan, 1946; Simeons, 1943; Hodes and Wood, 1945; Chaudhuri, 1943; and Parsons-Smith, 1944).

Clinically, in addition to the signs in the chest, the spleen and glands may be enlarged, but no mention is made of involvement of the kidneys or any other organ. The disease does not tend to wax and wane in severity, and spontaneous recovery usually occurs after a long time without treatment.

The aetiology is obscure, but has been attributed to tyroglyphid mites found in the sputum (Carter, Wedd, and D'Abrera, 1944; Carter and D'Abrera, 1946a and b; Soysa, 1949; Hall, 1946). The Wassermann reaction may be positive and the Kahn weakly positive (Menon, 1945; Greval, 1940; D'Abrera and Stork, 1946).

All age groups may be affected (Viswanathan, 1948).

Differential Diagnosis. The present case thus shows many features of tropical eosinophilia, namely chronicity, high, persistent eosinophilia, asthmatic bronchitis, $x$-ray changes, and response to arsenic. Also the patient had lived in the tropics. The haematuria could be explained as an unrelated event.

The condition differs from periarteritis nodosa in several respects. The course of the tropical disease is less severe and fulminating. The x-ray changes are diffuse and not distributed along the lung arteries (Elkeles and Glynn, 1944; Harris, Lynch, and O'Hare, 1939). The eosinophilia is higher than that usually seen in periarteritis nodosa (Rich, 1942; Tisell, 1941 ; Harkavy, 1941 ; Lovshin and Kernohan, 1948); and the response to arsenic does not occur in that condition. Haematuria can occur in periarteritis but oedema is rare (Mayo Clinic Symposium, 1949). Löffler's syndrome (Löffler, 1932), or eosinophilic pneumonia is a much milder and more transitory disease. The eosinophilia is not great and the lung changes are transitory localized opacities, never a diffuse mottling. The 
conclusion reached was that the patient had been suffering from tropical eosinophilia contracted in India, and that acute nephritis developed on her arrival in Britain. Whether this was precipitated by the climatic change, and whether the tropical eosinophilia was a factor in its development, are questions we are unable to answer.

\section{Summary}

A case with gross eosinophilia, asthmatic bronchitis, and acute nephritis is described. The patient had recently returned from India.

Our thanks are due to Professor W. S. Craig for permission to publish this case and for much valuable advice. We are indebted to Professor C. J. Polson for the biopsy report, Dr. J. Wall and Dr. C. Pickard for the radiological reports, and to Dr. W. McIntosh for access to the case records.

\section{REFERENCES}

Apley, J., and Grant, G. H. (1944). Lancet, 2, 308.

A , (1945). Ibid., 1, 812.

Carter, H. F., and D'Abrera, V. St. E. (1946a). Trans. roy. Soc. trop. Med. Hyg., 39, 373.

(1946b). Indian med. Gaz., 81, 284.

—, Wedd, G., and D'Abrera, V. St. E. (1944). Ibid., $79,163$.

Chaudhuri, R. N. (1943). Ibid., 78, 575.
D'Abrera, V. St. E. and Stork, K. G. (1946). Indian med. Gaz., 81, 282.

Elkeles, A., and Glynn, L. E. (1944). Brit. J. Radiol., 17,368 .

Frimodt-Möller, C., and Barton, R. M. (1940). Indian med. Gaz., 75, 607.

Greval, S. D. S. (1940). Ibid., 75, 676.

Hall, G. A. M. (1946). Brit. J. Tuberc., 40, 124.

Harkavy, J. (1941). Arch. intern. Med., 67, 709.

Harris, A. W., Lynch, G. W., and O'Hare, J. P. (1939). Ibid., 63, 1163.

Hodes, P. J., and Wood, F. C. (1945). Amer. J. med. Sci., $210,288$.

Irwin, J. W. (1946). Ann. intern. Med., 25, 329.

Lal, H. B. (1945). Indian med. Gaz., 80, 30.

Löffler, W. (1932). Beitr. Klin. Tuberk., 79, 368.

Lovshin, L. L., and Kernohan, J. W. (1948). Arch. intern. Med., 82, 321.

Mayo Clinic-Symposium (1949). Proc. Mayo Clin., $24,17$.

Menon, I. G. K. (1945). Indian med. Gaz., 80, 24.

Parsons-Smith, B. G. (1944). Lancet, 1, 433.

Rich, A. R. (1942). Johns Hopk. Hosp. Bull., 71, 123, 375 .

Simeons, A. T. W. (1943). Indian med. Gaz., 78, 271.

Soysa, E. (1949). J.R. Army med. Cps., 92, 1.

Stephan, E. (1946). Lancet, 2, 236.

Tisell, F. (1941). Acta Med. scand., Suppl. 123, p. 284.

Treu, R. (1943). Indian med. Gaz., 78, 70. (1944). Ibid., 79, 511.

Viswanathan, R. (1948). Quart. J. Med., 17, 257.

Weingarten, R. J. (1943). Lancet, 1, 103. 